\title{
近隣住民による屋外共用空間の保全・再整備に関する研究 \\ 一大都市の低層住宅地を対象として一
THE CONSERVATION AND RE-IMPROVEMENT
OF OUTDOOR COMMON USE SPACES
FOR NEIGHBORHOOD RESIDENTS

The case of low-rise housing areas in the metropolitan area

\author{
藍 澤 宏*, 浅 野 智**, 鈴木直子*** \\ Hiroshi AIZAWA, Satoshi ASANO and Naoko SUZUKI
}

\begin{abstract}
We deal with low-rise housing areas in the metropolitan area as the object of this paper, and look upon the close-at-home outdoor spaces (e.g. paths, parks and squares) as common use spaces for neighborhood residents. This paper analyses the special character, functions and roles of the common use spaces, and the planning elements that residents can take part in conservation and re-improvement of the spaces. The method of the analyses is to compare the utilization of the spaces and the consciousness of the spaces with 3 different housing areas. As the result of the analysis, we can find that the common use spaces are tend to exist within residents' cognitive territories, some different spaces take partial charge of roles each other, and squares have some subjects for conservation and reimprovement to take over as the valuable common use spaces for residents.
\end{abstract}

keywords : outdoor common use spaces, neighborhood residents, cognitive territory, conservation, re-improvement, squares 屋外共用空間 近隣住民 認知領域 保全 再整備 広場

\section{1.はじめに}

(1) 研究の背景と目的

昭和 61 年伊豆大島火山噴火や平成 7 年兵庫県南部地震等、自然災 害時等における住民の避難行動においては、地域社会の連携や連帯、 地域コミュニティの形成とその機能が、避難時や復旧時に重要な役 割を果たすことが様々な場面で論じられている ${ }^{11}$ 。この様な緊急時 や災害時に機能する地域コミュニティのありようは、日常の近隣交 流を形成する道路、広場、公園、あるいは地域行事や組織活動を行 う公共施設等の共用空間の使い方に強く反映する。

大都市の既成住宅地においても、住戸近傍の屋外の路地や広場等 が近隣住民の共用の場としての役割を果たしている場合が多い。東 京都中央区の月島·佃地区や、文京·台東区の谷中・根津·千駄木地区 等では【路地】隙間」と呼ばれる各住戸沿いの通路部分が日常の井戸 端会議や子供の遊び場、住民の覟い場として利用されており、それ ら身近な通路部分が住民の共用空間として評価され、かつ住宅地計

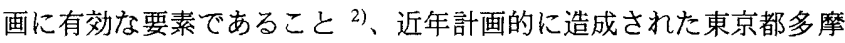
市の諏訪・承山団地等の低層住宅地においても、住棟群に囲まれた共 用庭・通路部分が近隣住民間交流を支援する空間として機能を果た していること ${ }^{3)}$ 、等が多くの既往調查研究で実証されている。

しかしながら多くの既成住宅地の場合、生活道路における自動車
交通量增加に伴う遊び空間の喪失や、都心地域に多くみられた居住 者転出・近䇟交流意識の低下等よる地縁性の希薄化、生活様式の個 人主義的な変化に伴う共用概念の消失、個別意識の浸透 ${ }^{4)}$ 等、諸々 の要素が複合した住宅地变容過程のもとでの身近な共用空間の継承 が困難な状況である。その対応策の一例として、住民参加型の整備・ 運営形態をとる身近な小規模広場、世田谷区太子堂地区等における 「街角広場! 整備が挙げられ、筆者らの既報 5】では、この広場が各世 代の地域住民により日常的に用いられ、かつ身近な空間として役割 を担っていること等を求めた。これらのオープンスペース整備に関 する近年の動向を踏まえ、今後の大都市既成住宅地においては、住 民が屋外の身近な領域内に共用する空間を有することが必要と捉え られる。そして住民要望に応じる形で既存屋外空間の評価点を保全 し、また問題点改善のための再整備を施すことが、近隣間交流に代 表される地域内連帯を維持・継承させる観点から重要と考える。

そこで本研究では、大都市における低層住宅地のオープンスペー スを、地域コミュニティ形成の重要な側面である日常の活動や近隣 交流を支える共用空間のストックとして捉え、近隣住民が屋外にお いて公·共·私の所有形態に関わらず共的に利用している空間・場を [屋外共用空間] (以下、共用空間)と定義し、(1)近隣住民による共用 空間の利用内容・形態等の利用の特徵、(2)それらの共用空間の機能

\footnotetext{
* 東京工業大学文教施設研究開発センター 教授・工博

** 建設省 工修

**** 東京工業大学文教施設研究開発センター 助手・ I修
}

Prof., Research and Development Center for Educational Facilities, Tokyo Institute of Technology, Dr. Eng.

Ministry of Construction, M. Eng.

Research Assoc., Research and Development Center for Educational Facilities, Tokyo Institute of Technology, M. Eng. 
と役割、及び計画課題、(3)そして今後の住宅地計画における共用空 間整備の計画要件を求めることを目的とする。

\section{(2) 研究の方法}

都市の既成住宅地における身近な空間 [街角広場] を扱った筆者ら の既報 5)では、広場の配置面を含めた整備要件を明らかにし、複数 の広場相互間の関係付けに際しても言及した。しかしながら、身近 な空間としての広場に対象を限定し、公園や避歩道、道路空間等、 他のオープンスペースとの関連については次の検討課題として残っ ていた。従って本報では、それらの空間を含め総体としての身近な 共用空間を研究対象として取り上げる。また、住宅地が形成された 過程により利用可能な屋外空間構成等が異なるため、同じ形状の空 間であっても利用形態が異なる場合と、地域により形状が異なる空 間であっても共通の利用形態を示す場合が存在する。

そこで、各住宅地に適用可能な一般解、住宅地ごとの特性が起因 する形で生じた特殊解の双方を求めることが共用空間の保全·再整 備に要されると捉えていく。研究対象地として、(1)狭险道路が網目 状に広がり、これらの路地等が共用空間として住民に形成・維持され ている既成住宅地から墨田区京島 3 丁目地区(以下、京島)（2)広場・ 公園等、屋外共用空間の設置も含め計画的に造成された低層住宅地 から、1982 年に入居開始後 15 年程度が経過した多摩市鶴牧 $3 \cdot 4$ 丁 目、落合 5 丁目のタウンハウス形式の団地(以下、多摩)、(3)居住域再 編下で街角広場等の新たな共用空間が形成されつつある既成住宅地 から世田谷区若林 4 丁目地区(以下、若林)を選定した(図 1)。

研究方法は、第一に近隣住民による共用空間利用の位置分布の特 徵を把握するため、住民が実際に利用している共用空間の位置を居 住位置との関連で捉え、その共用空間の位置と住民の認知領域との 関係を求める。第二に、共用空間の機能と役割を求めるため、共用 空間の性格区分を行う。対象地区の共用空間を形状・利用形態等に より類別し、地区ごとに各共用空間類型の分布状况、機能、類型間 相互の関係を捉える。第三として、今後の共用空間のあり方を求め るため、身近な屋外空間に対する住民の認識内容を捉え、その空間 整備と要望内容から保全·再整備に関する要件を明らかにしていく。

\section{（3）調査の概要}

本研究では、(1)住民による認知領域の区分、(2)屋外空間の共用実 態、(3)共用空間に対する住民の認識、(4)身近な屋外空間に対する住 民の意向の 4 点を内容としたアンケート調査を、3 地区ごと各世代 の住民を対象に実施し、有効票計 495 票が得られた(図 1 )。調查方法 は、(1)に関しては認知領域の範囲を調查票上の地図に記入してもら う方法、(2)は利用している屋外空間の位置・利用頻度・利用者構成· 行為内容を尋るる形式、(3)については利用空間の特徵や評価、整備 要望に関する内容を回答してもらう方法である。(4)は利用の有無に 関わらず、住民の身近な屋外空間に対する評価・要望を尋ねた ${ }^{6)}$ 。ま た、、各地区の空間構成·地域特性については、対象地における観察調 查、及び町会組織・区役所職員・団地の管理組合員に対するヒアリン グ調査により把握した。

\section{2. 分布状況からみた共用空間の特徴把握 \\ (1) 住民による認知領域の規模把握}

住民による認知領域(けワバリ 7)」と認知している領域、及び家 の近所 ${ }^{8)}$ と認知している領域の 2 種)の規模を算定し、各地区にお
いてその規模に相当する居住単位(両隣程度、班単位、町会単位、街 区単位、団地単位等)を把握する。具体的には、住民による認知領域 を調查票地図上の記入回答に基づき各領域の面積を求め、領域の形 態を円状に近似させる形で平均半径を求めた(図 2)。また、認知領域 に対する空間の位置関係、地域内の主な居住単位との対応関係を捉 えるため、身近なオープンスペースの認知領域に対する包括度合を 併せて把握する。京島の場合は町会域中央部の生活道路 ${ }^{9)}$ と町会域 外縁部に位置する公園、多摩·若林の場合は団地·住宅地群内の最奇 の小広場と団地·住宅地群外の最寄の公園を対象に扱う。

まず、各地区のけワバリ領域の特徵を捉える。京島·若林のけナ ワバリ領域は半径約 $30 \mathrm{~m}$ の領域に該当する。この篹域は、京島で の概ね町会の下部組織にあたる班単位規模に相当し、若林では概ね 周辺 10 戸程度を包括する範域、即ち地域組織の基礎単位である隣組 と同等である ${ }^{10)}$ 。一方多摩のけワバリ領域は半径約 $40 \mathrm{~m}$ と大き いものの、周辺 10 戸程度が該当している。各地区に共通して、認知 するけワバリ領域と身近な居住単位との範域が対応している傾向 がある。また、けワバり領域内に該当する共用空間の内容を見る。 多摩地区では、回答者の約 4 割が最寄の広場をけワバリ領域内に 位置づけており、住民の身近な認知領域内の広場が利用される傾向 がある。一方、若林地区の場合、最寄りの広場をけワバリ」領域内 に位置づける回答者は全体の 1 割程度と少ない。この広場はその位 置設定が住民からの申し出による行政の用地買収であるため、地域 全体のバランスを考慮した均等配置ではなく、住民のけワバ!」領 域内に取り込まれにくい状況を呈している。

次に各地区の [近所! 領域内の共用空間の特徵を捉える。京島・若林 地区の 近所]領域の範域は平均半径が約 $130 \mathrm{~m}$ と同じである。京島 地区では行政町丁界域が複数の自治町会に分かれており、町会域単 位が 近所 領域の居住単位として認識され易い傾向にある。主な共 用空間の 近所了領域内の包括状況に着目すると、町会域内の道路の 約 9 割を[近所]領域内に位置づけており、沿道住民を中心に身近な 認知領域内に取り込む傾向が強い。一方最奇の公園は、近所 領域 内とする者が 5 割に満たず、認知領域外としている者の割合が多い。 京島では[近所」の認知領域と自治町会域との領域対応が強いが、 若林地区では町会域単位が複数の行政町丁単位に相当し、地域組織 単位と認知領域との領域対応がそしい。そのため若林地区の「近所了 領域は、幹線道路、商店街、生活道路が認知領域境界となりやすい。 また若林では、公園群の位置が商店街や駅と方向が異なるためか、 最寄の公園を「近所】範囲内と認知する者の割合が全回答者の 2 割強 にとどまっている。大規模オープンスペースが他の生活利便施設と 区分されると特定領域として住民が判断する傾向が見られる。

一方、多摩の「近所门領域は半径約 $150 \mathrm{~m}$ と京島·若林に比べ大きい。 団地に隣接する最奇りの公園については、回答者の8 割に近所内 の空間として位置づけられ、住民の大部分が居住する団地のみなら ず隣接するオープンスペースについても認知領域内に取り込む傾向 がある。これは公園を近隣住区の中に取り入れる内容が計画時点で 存在し、住民も共用空間を近所と認識している結果と考えられる。

（2）分布状況からみた屋外共用空間の特徽

屋外共用空間を居住位置との距離に着目し、分布状況を地区別、 住民の個人属性別に求め、各地区の屋外空間構成之利用者の特徵を 明らかにする(図 3 )。設定した個人属性は、住民の年龄階層や就業形 
態、同居家族内の幼児・児童の有無、居住年数の相違が認知領域の捉 え方に反映するものとし、(1)供·若年・壮年·老年の年龄層·性別に 関する区分 ${ }^{11)}$ 、(2)居住歴に関する区分 ${ }^{12)}$ を分析基準とする。

地区別の特徽をみる。京島地区では、若い世代から高齢者層に至 るまで、共用空間分布が各属性ごとの認知領域区分の近所」に集的 される共通点がみられる。更に、各世代の女性は同世代の男性と比 べ領域的には狭い分布形態を示し、壮年·老年層の女性の場合は、共 用空間を概小けナバリ内で利用する傾向が強い。居住歴に着目す ると、居住歴が長くなる程「近所」領域が町会域程度の規模に収束し ていく傾向が見られる。!11〜30 年! と比較して 31〜 50 年」51 年〜」 の階層が概ねけナワバリ」へ収束しており、永年定住者が住戸近傍の 狭域な領域内に共用空間を持つ傾向が認められる。京島地区では住 民の認知領域規模が町会域や班単位等の居住単位と年齢的・性別、 居住歴等の個人の属性と対応し、共用空間分布の特徵が存在する。

多摩では、子供·若年層の若い世代が共用空間を[近所] 領域に、壮 年・老年の女性を中心とした階層が概ねけナワバリ領域内に位置づ ける傾向にある。住戸近傍には小規模の、団地外縁には大規模の才

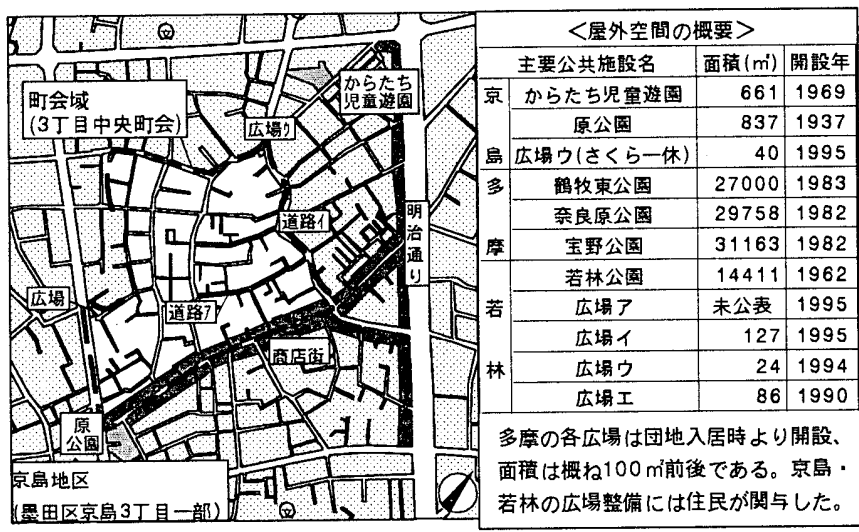

<地域組裁と空間管理運営>

京帛: 中央町会には600世带が加入、年中 行事として老人会・子供による道餎 の清挤が為され 辺住民が管理。

多席 : 団地每下住民組管理組合が存 広場や道路の清掊は業者と周辺住民 が行5他、年2度住民組䋘が行

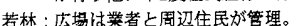
〈調查票回答者の挠成〉
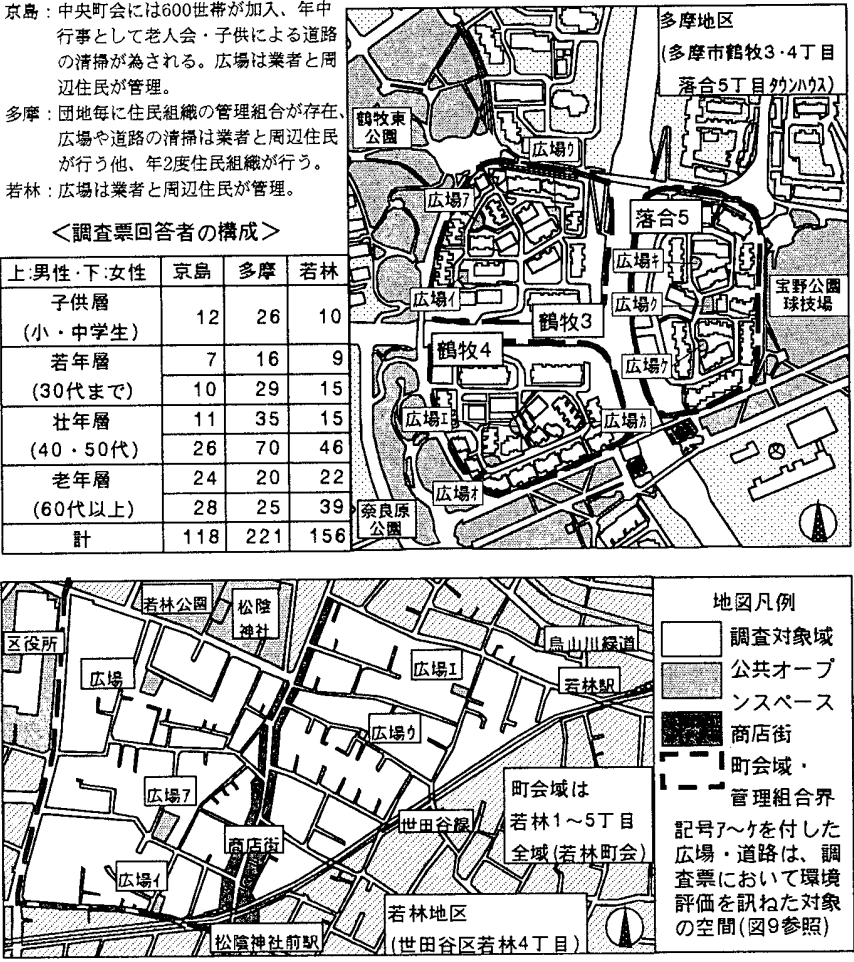

図1 研究対象地の概要と調査票回答状況
ープンスペースがそれぞれ確保された屋外共用空間の構成があり、 京島と比べ世代間における共用空間分布の使い分け、領域区分が顕 著である。すなわち、高齢者層等の在宅時間の長い階層が身近な領 域内の小規模な共用空間を利用し、若年層がその周辺部分の大規模 な共用空間を利用する傾向がある。また、住民の認知領域において も近接するオープンスペースと、大規模オープンスペースそれぞれ において認知の領域を明確に区分している。

若林地区では、壮年·老年層の女性、居住歴の長い階層の共用空間 分布が概小けワバリ」領域に対応する。すなわち、在宅時間の長い 階層や定住者層が身近な認知領域内に共用空間を形成し、京島·多摩 両地区と同様な特徽が見られる。一方、子供層・若年層、壮年・老年 男性に関しては、共用空間分布が「近所」内から外側へと桩がる点で 京島・多摩と大きく異なっている。これは「近所」領域に対応する町会 や団地等の居住単位の存在がなく、各人の共用空間分布と認知領域 規模との関連づけがしにくいことが理由と考えられる。他の特徴と して身近なけワバリの他に、大規模オープンスペースを認知領域 外の共用空間として位置づける住民がこの地区には多い傾向がある。

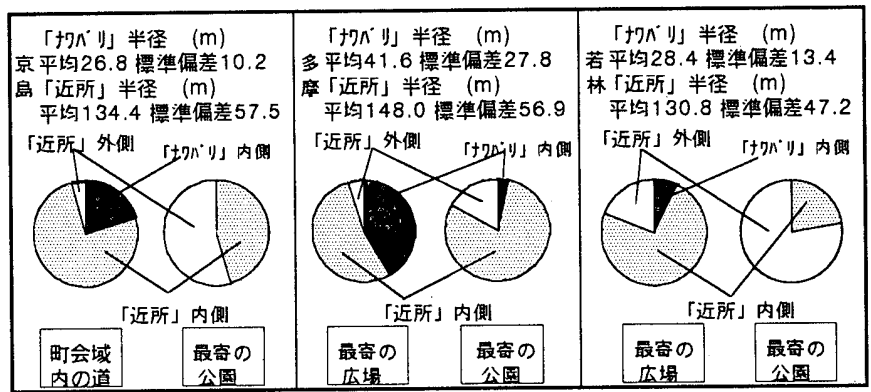

図2 地区別認知領域平均規模と屋外空間の包括度合
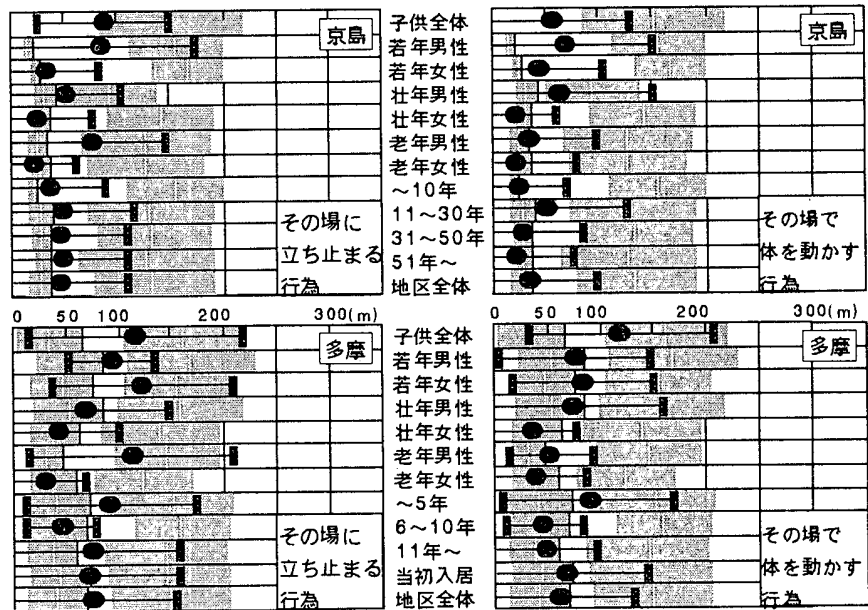
子供全体
若年男性
若年女性
壮年男性
年年女性
年男性
年女性
$\sim 5$ 年
$6 \sim 10$ 年
11 年
当初入居
地区全体
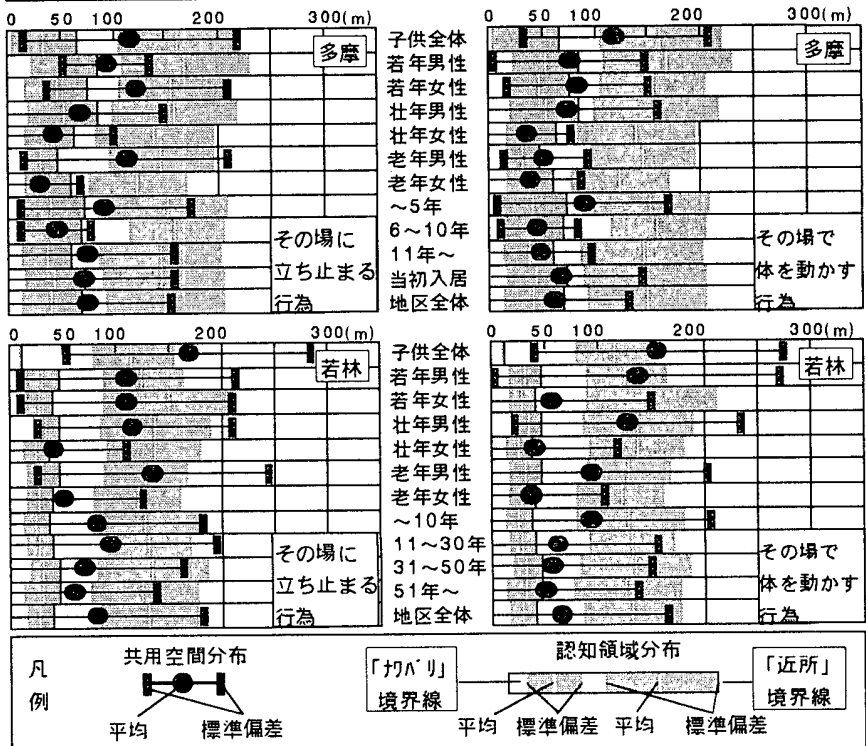

$\left\lceil+7 n^{\circ}\right.$ ⿰丨丨
境界線 袐知領域分布 為

端の項目は年龄層7区分・居住歴4区分，横軸の数字は居住位置からの距離を示す。 その場に立ち止まる行為・その場で体を動かす行為の構成については图6参照。

図3 共用空間分布と認知領域区分との対応 


\section{3. 屋外共用空間の機能と役割}

\section{（1）屋外共用空間の類型化と各類型の特徵把握}

各地区の共用空間の特徵が、住民の共用空間の利用に影響を与え ているか、言い換えれば共用空間の構成が住民の利用をどの様に規 定するかを求めるため、住民利用から見た共用空間の類型化を行う。

共用空間を特徵付ける指標設定の視点として次の 2 点を挙げる。 第一点は、共用空間における日常的な屋外活動として、1人での活動、 家族内交流、近隣住民間交流等の利用内容、第二点は、共用空間を 構成する設備、道具、樹木等の自然要素の有無、及び場の安全性、 快適性などに関する空間要素である。第一点に関しては、(1)どのよ うな状況で、(2)どのような集団構成で、共用され易いか、共用実態 の側面から屋外空間を意味付けること、第二点は共用空間を成立さ せている多様な性格を明らかにすることである。以上の視点により 空間共用に関する 10 項目、空間把握に関する 16 項目の計 26 項目を 指標に構成し、それらを用いた主成分分析を行う(図 4 )。

共用空間の主成分分析のサンプル構築については、各地区毎の道 端〕角地」[袋小路(共用庭)」「広場】 [公園」の各共用空間を、(1)静的 な立ち止まる行為、(2)動的な体を動かす行為の 2 区分 ${ }^{13)}$ 毎に、さら に[道端!角地に関してはさらに最奇りと遠隔の 2 つの距離区分に 分け、京島では 12 サンプル、若林では 15 サンプル、多摩地区では 16 サンプル、全体では 43 の共用空間を設定した。指標内容はサンプ ル毎に、各指標に対する該当者数で除した、百分率である。固有値、 累積寄与率は図 4 に示す。主成分分析の軸の考察範囲は寄与率が若 干低いものの立体構造として考察可能な 3 軸までを考察対象と扱う。 1 軸は、プラス側に「花や樹木がある!広くゆとりを感じる!邪魔 な物がない」車が少なく安全]等の安全性·快適性に関する指標、共 用形態項目 [同伴家族人数」が奇与する。一方マイナス側には知人に 会いやすいj 人が多くにぎやか」の空間把握項目、共用形態 近瞵交 流利用頻度」の寄与が高い。プラス方向は空間の快適性·安全性が総 合的に高く評価され、かつ家族により共用される場合、マイナス方 向は空間の安全性·快適性の評価が低く、かつ近隣住民により共用さ れる場合を示す軸と意味付けられる。2 軸は、プラス側に利用者率 を示す指標が寄与し、プラス方向は多数住民により共用される場合、 マイナス方向は少数住民による共用の場合を示す空間利用度合の軸 と意味づけられる。3 軸は、プラス側に「路面が安定している|清掃 や手入れがしてある」 1 人利用頻度」等清掃に関する項目、マイナス 側には、付帯設備に関する「遊具や砂場がある!座るところがある、 並びに共用形態項目门近隣交流同伴者人数〉が収噞している。プラス 方向は管理側面が重視され、1 人利用され易い場合、マイナス方向は 管理側面よりむしろ付帯設備が重視され、かつ複数人数に共用され る場合を区分する軸と意味付けられる。

以上のように意味付けた各軸のサンプル主成分得点値を用い、ク ラスター分析による共用空間の類型化を行い ${ }^{14)}$ 、各座標系における サンプル群布置形態から、Space1〜7(以下 S1〜S7)に分類した(図 4)。

S1 は $2 \cdot 3$ 軸プラス側に布置され、多数住民が共用し主に 1 人で の活動に供され管理側面の重視された空間と捉えられる。S2 は 2 軸 上の原点付近に分布しており、S1 と比べ利用度合が低い。1 軸上に 関しては $\mathrm{S} 1$ よりマイナス方向へ突出し、3 軸負であることを踏まえ ると、近隣交流がなされ管理側面が重視されていない空間として意 味付けできる。S3 は主に 3 軸のプラス、すなわち管理側面重視の点
で S1 と類似する。2 軸上では S2 と同様原点付近の分布となり、S1 と比べ利用度合が低いとみなせる。1 軸に関しては $\mathrm{S} 1$ と比べ正方向 に布置され、S1 より空間に対する環境評価の高い空間と意味づけら れる。S4 は 2 軸マイナス方向の分布形態をとり、少数の住民の共用 空間と見ることができる。S5 は2 軸マイナス側に分布し少数の住民 の共用空間と意味づけられ、1 軸·3 軸プラスにそれぞれ突出し、共 用空間で空間環境が評価され管理側面の重視された空間と位置づけ られる。S6 は S1 と同様 2 軸プラス方向に分布し、多くの住民による 共用が認められる。1-3 軸座標系では S1 と対極にあり、多数の共 用空間、家族交流に供され付帯設備の重視された空間と見ることが 可能である。S7 は 1 軸プラス方向に分布する点で S5:S6 と同傾向に あり、 2 軸・ 3 軸負に分布し、付帯設備重視の点で特徽づけられ、少 数の住民の共用空間で家族交流に利用され付帯設備のある空間と見 られる。以上のように共用空間の性格区分として、空間の環境評価 内容·集団構成、利用度合、及び管理/設備に対する関心·単数愎数利 用の相違、により意味づけられる7 類型を抽出した。共用空間は $\mathrm{S} 1$ ： S6 に該当する主要な空間と、他の要素が特化した副次的空間に二分 される構造を持っていることが把握できた。

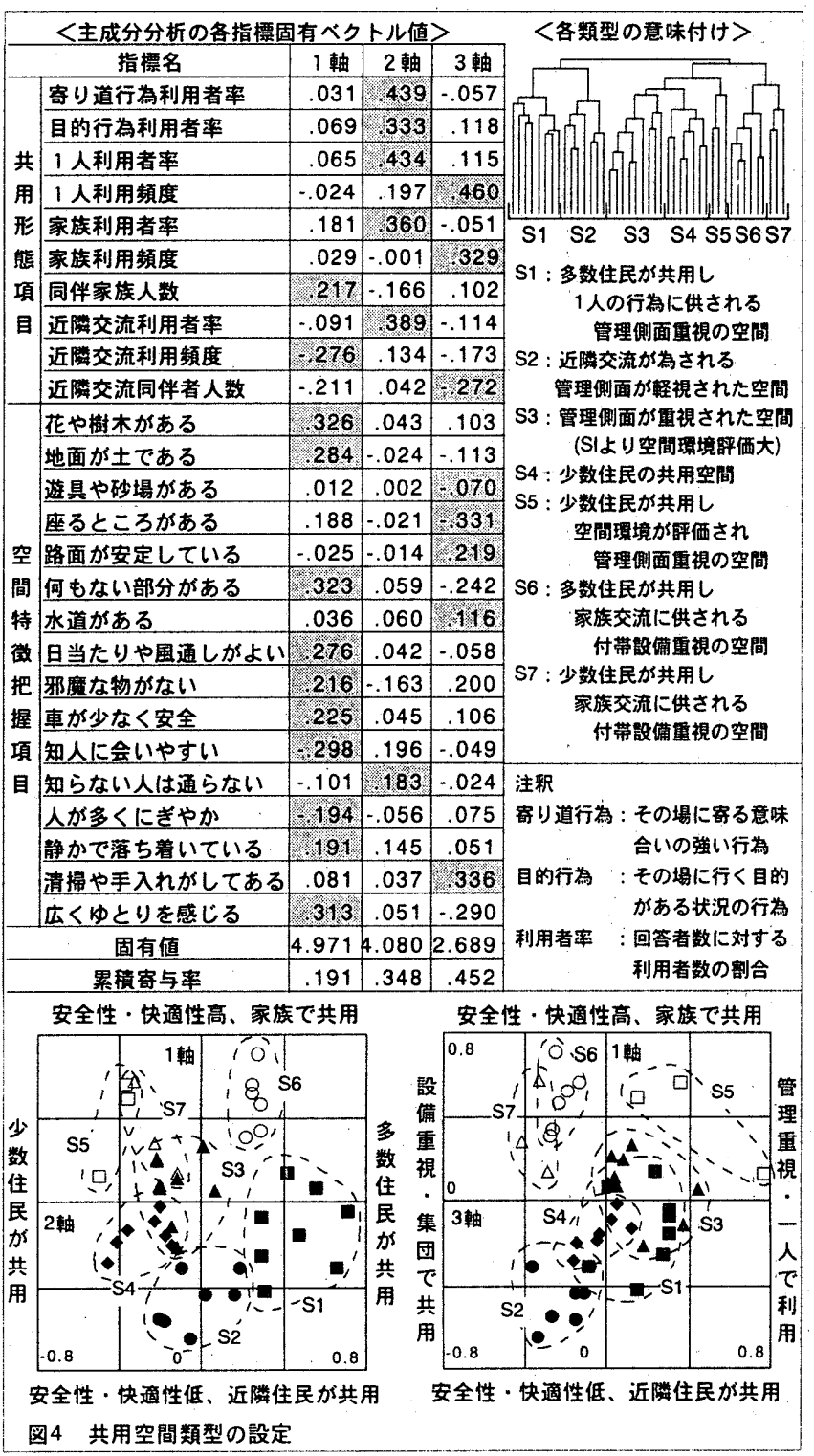




\section{（2）地区単位で捉えた屋外共用空間の機能·役割}

共用空間類型 S1〜S7 の各地区における分布形態について、共用空 間の距離帯分布と認知領域区分との対応関係、及び各類型の分布状 況との関連の特徵を見ていく(図 $5 \cdot 6)$ 。また、各々の共用空間が各 地区で果たしている機能·役割を、各類型の認知領域内分布と各類型 に対する利用者の活動内容·個人属性、並びに活動の状況別空間併用 を併せて捉えていく(図6.7・8)。

京島地区では S1·S2·S3·S4 の 4 つの類型の共用空間が多くを占め る。S1には身近な道路空間が該当し、ナワバリ! 領域内に集約する。 S2 には最寄以外の道端·角地、並びに袋小路が該当している。いず れも[近所 の範囲内の分布であり、居住位置より半径 $100 \mathrm{~m}$ 内外に 共用空間が存在している。 $\mathrm{S} 1 \cdot \mathrm{S} 2$ は道路空間が主な場であり、管理 側面重視・ 1 人利用に供される!、近隣交流がなされる など 1 人と 複数等の双方の性格の場を担っている。一方 S3 の広場は 近所! 領域 内、S4の公園は [近所] 領域外に対する段階的な分布形態をとる。京 島では S1·S2 に該当する道路(道端·角地·袋小路)が主要な共用空間 と位置づけられるので、それらの特性について考察を進める。S1·S2 の活動内容をみると、「通り抜ける!清掃・花の手入れをする」の必 須行為のみならず、揭示板を見る!位ち話をする!子守をする! 「遊びの相手をする もなされ、地域倩報授受や子供の遊びを介した 他者との交流機能がみられる。また利用者属性については、概ね子 供層から老年層に至る幅広い構成が認められる。身近な領域内の道 路空間が、幅広い利用者層、複数機能を有する意味で共用空間拠点 として役割を果たしている特徴が見られる。また、道路空間では日 常行為·交流活動を担う機能を有するものの余暇活動の利用はみら れず、道路空間は余暇活動の代替空間としては機能せず、別に余暇 空間としての場の必要性が求められた。

多摩では主要な共用空間として S1·S6 が存在する。S1 は身近な道 端が該当し「ナワバリ内に属し、S6 は道端·遠隔」公園・最寄」が該 当し[近所!に収まる。また S1 以外のけワバリ」に属する空間として、 S3 の身近な角地・共用庭、S4 の共用庭と広場・最寄]、S7 の広場が 挙げられる。従って、けワバリには主要空間 S1 と、性格の特化し た S3·S7 が混在し、S1 と対極をなす S6 がけワバリ」の外近所内 に存在する特徽がみられる。空間の利用状況をみると、その場に立 ち止まる行為、その場で体を動かす活動の双方を、(1)にけワバリ 内にある道路空間(S1)で行う住民、(2) [近所了範囲内にある S6 で行う 住民、(3) S1·S6 両空間を活動の相違により使い分ける住民がそれぞ れ存在する。更に $\mathrm{S} 1$ - S6 における住民の活動内容・個人属性をみると、 S1 は主に壮年·老年の女性層による「立ち話する「清掃·花の手入 れ等の日常行為の場として、S6 は主に子供·若年層によるにと休 みする「遊ぶ・運動する小余暇活動の場として、機能分化がみられ る。従って、けワバリ」内に共用空間の拠点が存在する他、近所」 においても主要な共用空間が存在し量的に充足していること、それ らの共用空間相互において機能の欠落を相補う役割分担が行われ、 地域内で共用空間の集合体として機能している。一方「ワバリ」領 域内に位置づけられる S7·S4(広場)では、これらの利用者は主に少数 の壮年·老年層の女性で構成され、にと休みする「清掃·花の手入 れ「立ち話をするが主要内容と捉えられる。主婦層が広場の管理運 営に携わりつつ、身近な共用空間として広場を機能させている状況 が求められた。すなわち女性層がけナワバリ」近所の両空間を、管
理・利用することにより共用空間が利用されやすくまた役割を担う。

若林地区では S1 に属する道端·最寄」、S2 の中の身近な道端·角 地、S3 の角地·袋小路がけワバリ」内に分布し、S3·S4 の広場・最 寄」についてもけワバリと近所の中間に位置づけられる。京島 との共通点として、同一の道路空間が管理側面重視 $\cdot 1$ 人利用に供

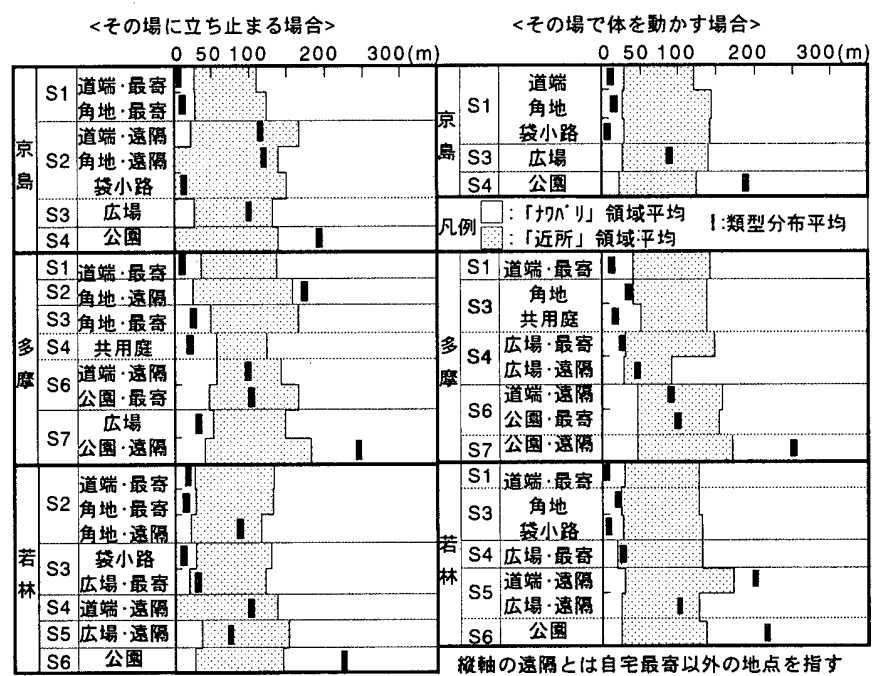

図5 類型別共用空間の距離帯分布と認知領域との対応

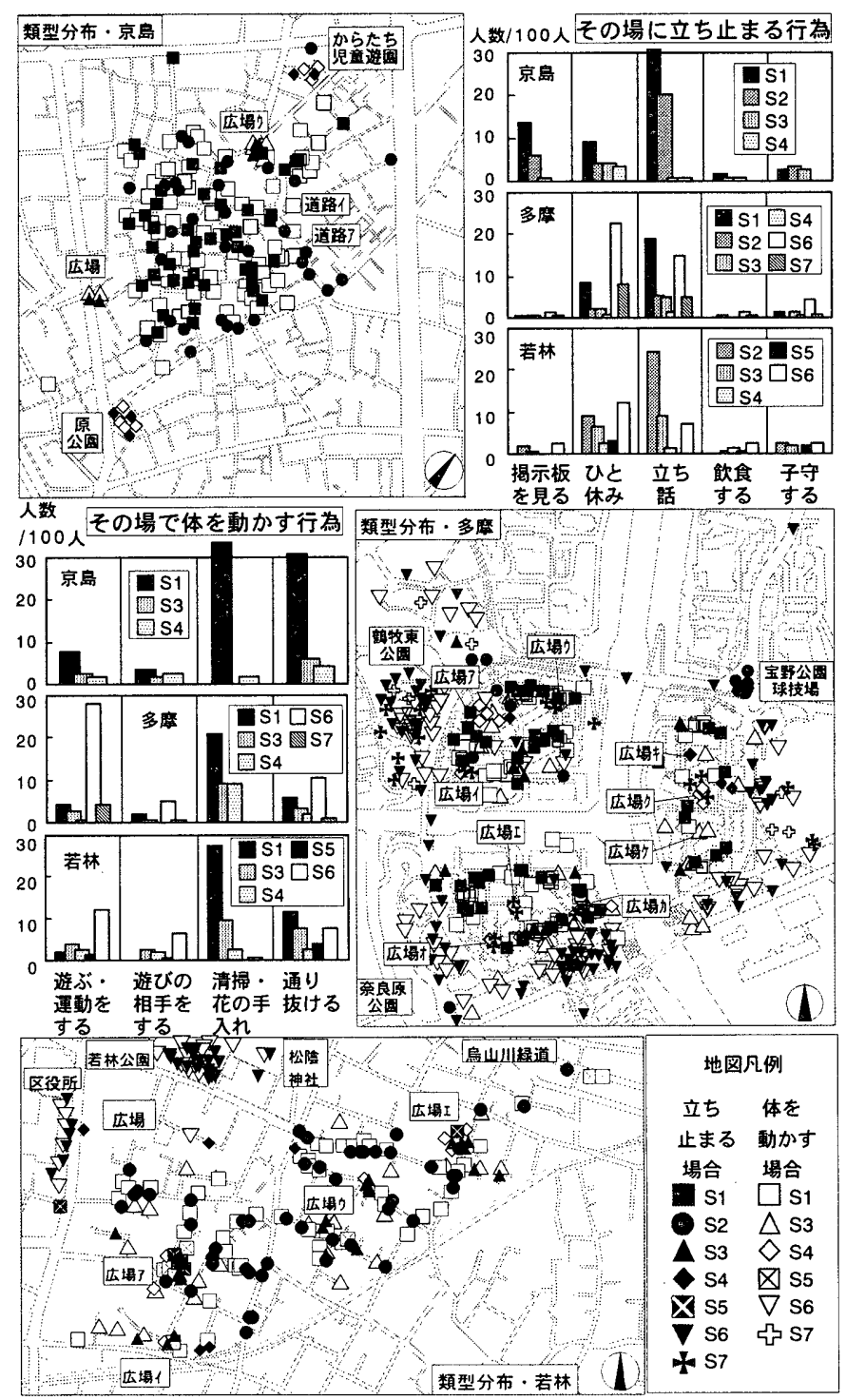

図6 共用空間類型分布と類型別行為内容

人数/100人民の場に立ち止まる行為 S3 通刑 $52 \square 56$ man. その場で体を動かす行為 颣型分布.多度 
される」・近隣交流が為される」の双方の性格を有すること、多摩と の共通点として、住民のけワバリ!に主要空間 $\mathrm{S} 1$ と性格の特化した S3 との混在が挙げられる。住宅地内に広場が整備された結果、旧来 からの道路空間主体の構成から、多摩のように異種混在が強まる構 成へと移行したと捉えられる。S6には公園が該当し、認知領域の外 側に位置づけられ易く、身近な S1 と隔たりが認められる。併用状況 に着目すると、多数の住民はけワバリ内の S1·S2(道端・角地)を共 用しており、身近な道路空間が共用空間拠点と性格づけられる。 $\mathrm{S} 1$. S2 における住民の活動内容·個人属性をみていくと、主に子供以外 の階層による「立ち話をする!清掃·花の手入れ」で構成され、他地 区と同様壮年·老年の主婦層が日常行為をとる共用空間 と解䣋され る。S6 をみると、子供から老年層に至る各世代がにと休みする!子 守をする!遊ぶ・運動する!通り抜ける!等を行っている。公園は多 機能を有し、幅広い世代の住民に共用された主要空間に位置づけら れるものの、計画的に住戸近隣にオープンスペースが組み込まれた 多摩と異なり、近所 内に認識され難い傾向にある。一方 S3(袋小路、 (広場・最奇」)の利用者の間では、それらが「ナワバリ」内に取り込ま れている場合、けナワバリにおける他類型(道路)との併用が認めら れる。また袋小路·広場における住民の活動内容·個人属性をみると、 ひと休みする」位ち話をする|子守をする!清掃・花の手入れを する等が比較的多く、概ね各世代で構成されている。S3 には余睱 行為、子供を介した交流行為を担う機能が認められ、すなわち多摩 と同様、住宅地群内の広場・袋小路が道路とは異なる共用空間の役割 を果たしている。

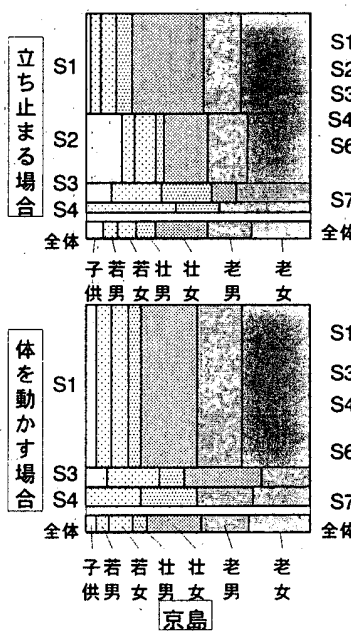

図7
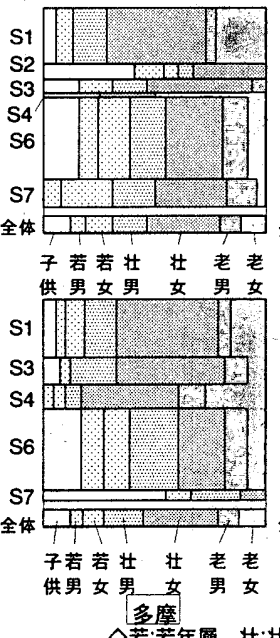
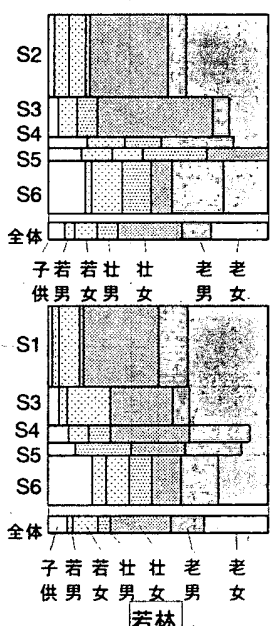
年層 老:老年盧 を示す 年層 老:老若椟 を示す

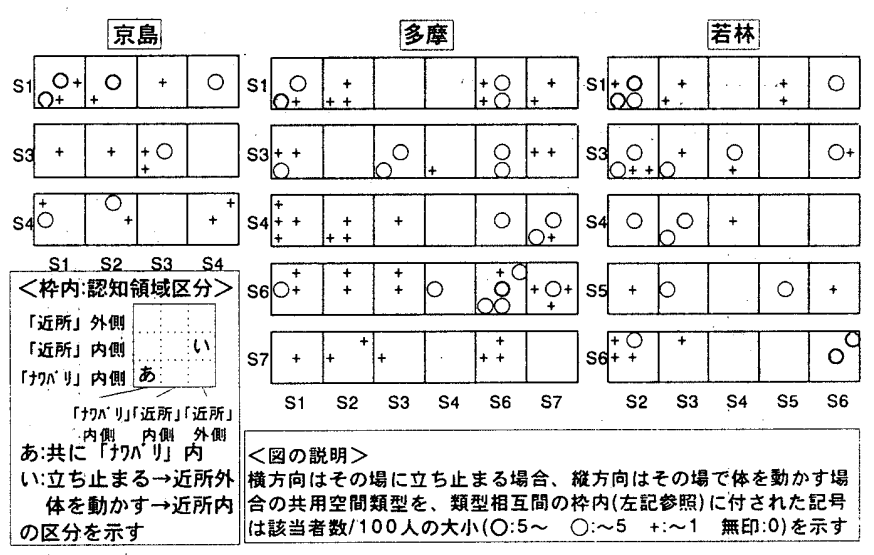

図8 共用空間類型相互の併用状況

\section{4 . 屋外共用空間の保全·再整備の方向性}

（1）近梦住民の利用評価による屋外空間の類型化とその特徵

近隣住民による屋外共用空間の評価を考察する。方法は、住民の 利用形態・空間評価による共用空間の類型化・評価認識と、空間の 整備内容とを対応させる。内容は、(1)共用空間整備に組み込む要素、 (2)利用者構成·利用形態から見た利用の多様性を考察の対象とする。 (1)は空間の領域的性格、安全性、快適性、付帯設備の整備状況に関 わる項目、(2)は利用者の年湛層、公·共・私に関する所有区分、利用 形態に関する項目を空間認識指標として構成した(表 1)。分析対象の 共用空間を整備対象別にするために対象空間の位置づけを行う。ま ず、身近な屋外空間として、， i ) 自宅前の道〕を各地区共通にとる。 次に ii ) 各地区の空間配置形態を考虑した上で、京島では広場と町会 域内の道、多摩・若林では複数の広場を選定した。表 2 に示すように 広場を整備内容により分類する。最初に、iii)-(1)腰掛けや植栽等㝆う 行為を支援するもの、砂場や滑り台等の遊具を配するもの、路面が 整備されスペースが確保されているものに該当する広場ウ(京島)、広 場イ・オ(多摩)、広場エ·ク(多摩:集会所中庭の立地からは中庭〕 と標 記)、広場ア・エ(若林)については、住民の䕀い・遊びに供される場と して滞留型〕と設定する。次に、iii)一(2)道路空間の一部に滞留機能 を付加させている広場ウ・カ・キ・ケ(多摩)は、通過機能を含めた!滞 留十通過型」とする。そして残りの iii)一(3)広場ア(多摩)、広場小・ウ (若林)は、植栽が設えられ、散策路・通路として通過機能を担う!通 過型り共用空間の整備から見た類型を設定した。

さらに、対象地域の該当する共用空間に対する住民の評価を捉え るため主成分分析を行う。サンプルは、各世代ごとの空間認識を把 握するため年臥層・性別による7区分を用い、デー夕は、対象 3 地区 における各年跉層の共用空間に対する認識指標の構成率、すなわち 各指標ごとの該当者数をサンプルにおける母数で除した構成率であ る。表 1 に主成分分析の固有ベクトル等を示す。1 軸は、正方向に人 が集う広さがある|座りやすいところがある!花や木が多い!日 当たり・風通しがよい「邪魔な物が置いていない等の付帯設備や快 適性、安全性に関する項目が総合的に収敛し、空間性能評価の大小 を示す軸と意味付ける。2 軸は負方向に顔見知りに会う!揭示板が ある!の地縁的性質の強い指標、|主婦達が集まる!お年寄りが集ま る 等在宅時間の長い階層による交流を示す指標、仔供達が集まる! 「遊んでいる人をみる!の子供の遊びを示す指標が奇与し、屋外空間 が住民間交流を担う度合に関する軸と意味付ける。サンプル得点値 を $1-2$ 軸座標系に布置し(図 9)、3 地区の身近な屋外空間を整備内 容の相違、住民の年齢層と対応させる形で特街付けていく。

京島では広場が 1 軸正方向に突出し、道路空間に比べ空間評価が 総合的に高いと認識されている。年齙層別の広場に対する認識では、 在宅時間の長い壮年女性·老年層に 1 軸正、すなわち空間評価大と強 く位置づけられる。一方 2 軸上では、これらの階層は比較的原点付 近から正方向に分布し、交流機能の高い空間とは認め難い。道路に ついては[町会域内の道」と比べ自宅前の道」が 1 軸正・2軸負に位 置し、特に壮年·老年層の住民が空間評価大·交流機能大となる。最 も身近な道路空間が快適な場所と位置づけられ易い傾向を把握した。 多摩においても、全体的に広場に関する各サンプルが 1 軸正に位 置し、空間評価大として幅広い世代に認識されている。広場整備内 容による区分ごとに分布を捉えると、滞留機能が備わるほど 1 軸正. 
2 軸負の方向へ偏り、空間評価大·交流機能大の空間としての認識が 高まる状況が強く認められる。老年層は「滞留十通過型〕について、 【中庭」と同様空間評価大·交流機能大と認識しているが、老年層によ る自宅前の道」の評価は低く、在宅時間の長い階層が身近な道路(空 間評価小)と広場(空間評価大)を異なる空間と認識する特徵を得た。

若林の場合は、「滞留型」が 1 軸正・ 2 軸負、「通過型」広場が 1 軸 負· 2 軸正、「自宅前の道! が 1 軸負・ 2 軸負と 3 極構造の分布をとる。 [滞留型】は子供等の若い世代が 1 軸正・ 2 軸負に突出し、高く評価さ れた遊び場・数いの場としての機能が捉えられる。一方通過型は、 花木が植えられ、通行者を和ませる要素がみられるものの、滞留型 に比べ空間評価·近隣交流の場としての認識が低い傾向が見られる。

以上のように、各地区とも滞留機能を有する広場は、各世代によ る安全性・快適性など総合的な空間評価が高く、かつ整備内容に応じ た形で利用者層を中心とした交流機能を担う空間に位置づけられ、

身近な道路空間に比べ優位性を有することを明らかにした。

（2）共用空間の保全·再整備

屋外共用空間の住民評価を前提条件とし、共用空間としての役 割・機能を保全・再構築するための方向性をまとめる。空間整備項 目には、空間の再整備や制度導入に関する 12 項目(自然物·付帯設備 の搪充、スペース確保、快適性·安全性の向上、管理徹底)を選定し ている。以下各地区ごとに分析考察を進める(図 10)。

京島地区については、路地等の従来から共用空間としての役割を 担ってきた道路空間が主要な場として位置づけられており、広場が 整備途上にあるため、道路と広場を対象に扱う。自宅前の道」は町 会域内の道 と比較して空間評価が高く、大部分の住民に満足された 空間とみなせる。住民は均質な道路空間の中でもより身近な空間に 対し高い評価を与え、かつ現状に充足している傾向にある。一方広 場については、价つと広くする!花や木を増やす!が多く、快適性 向上が望まれている。京島では、身近な道路空間の評価が高く重要 な役割を担っているのに対し、広場(滞留型)は、多摩の「中庭」「滞留 型」や若林の【滞留型」より評価が低い傾向を示しており、住民意見を 反映しつつ空間性能の向上を重点的に施すことが、利用者定着の点 からの再整備課題として得られた。更に道路と広場との比較を行う と、邪魔なものをどかす「車の通行を制限する」等の安全性に関す る要望が少ない広場に対し、総じて空間評価が高い[自宅前の道」の 安全性要望は多い。身近な道路空間のみにより近隣住民の滞留行為 を担うためには、空間整備項目として安全性確保を付加させる必要 があるが、道路という性質上限界性が認められる。安全性向上等の 解消が困難な道路空間に対しては、広場を多数住民の「ナヷリ」内 に配されるよう量的に拡充し、広場に道路空間補完の役割を担わせ ることが再整備の方向性と求められた。

多摩地区については、整備内容に相違がみられる広場が複数配置 された場合として空間再整備に関する考察を行う。広場を現状のま まで良いとする住民は、広場の整備形態に因らずいずれも、京島に おける自宅前の道」と同様に比較的多く、広場が現状で満足と位置 づけられる傾向にある。整備要望内容に着目すると、座るところを つくる「遊具を備える!等付帯設備の拡充に関しては比較的要望が 少なく、付帯設備が欠落した「通過型」においてもそれらの要望はあ まりタられない。しかしながら、他の広場には付帯設備が存在する ため、団地内の複数広場を集合体と捉えた場合、全体的に付帯設備

充足が認められる。「邪魔なものをどかす「「車の通行を制限する」の 安全性に関する要望についても、広場の整備形態に因らずいずれも 少ない。その中でも通過型〕の「車の通行を制限するが少なく、団 地内の通り拔け路としての機能が窺える。スペース確保に関するほ つと広くするについても、京島·若林の各屋外空間と比べ少ない。 団地に近接する形で大規模オープンスペース、住棟間に共用庭がそ れぞれ確保され量的に充足した現状とみられ、結果として広場に規 模確保の側面を担わせる意見が隇じると捉えた。多摩の広場に関し 比較的要望が多い項目には、「花や木を増やす」清掃を徹底する」 「静かな場所にする!が挙げられる。他地区と比べ空間評価が高く、 付帯設備·安全性·スペース確保の側面は充足傾向にあるものの、清

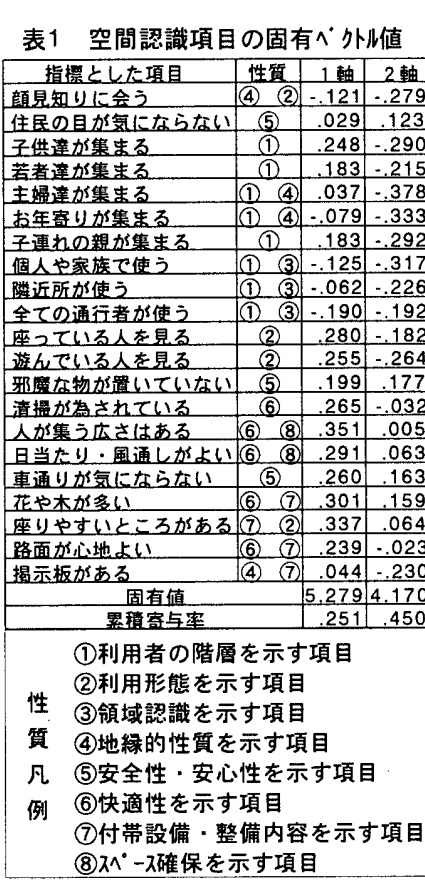

表2 空間整備内容による広場分類 乃〜多图1.6、類型名左の記号は图9に対志 京島 多䆣

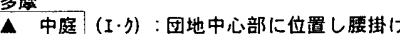

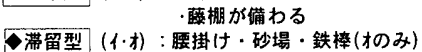
植载が備わる ○满留十(ウ力：通路部分と連続した空間に

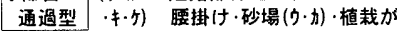
通過型（ア）: 通路としての空間に植载か 若林 滞留型(ア・I ）：腰掛け・植载の他、砂コンタリート の路面のス八゙-ス(7) - 砂場や滑 り台(I)が備わり，游で場と しての機能を有する

$\triangle$ 通過型 $(1 \cdot ウ) ：$ 通路として整備され植载か しつらえられている

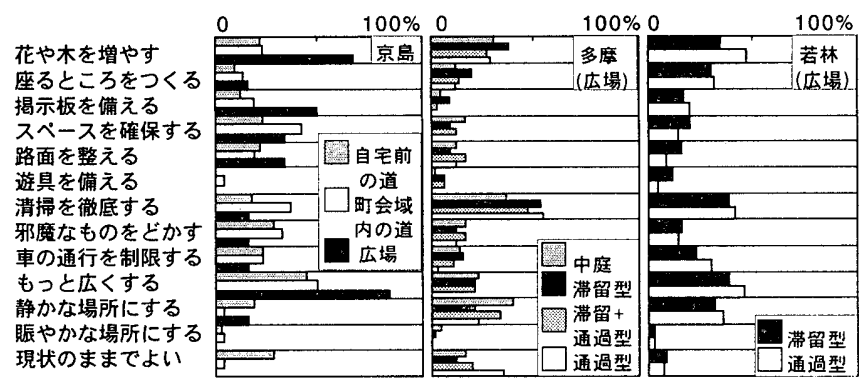

図 10 住民による屋外空間整備要望

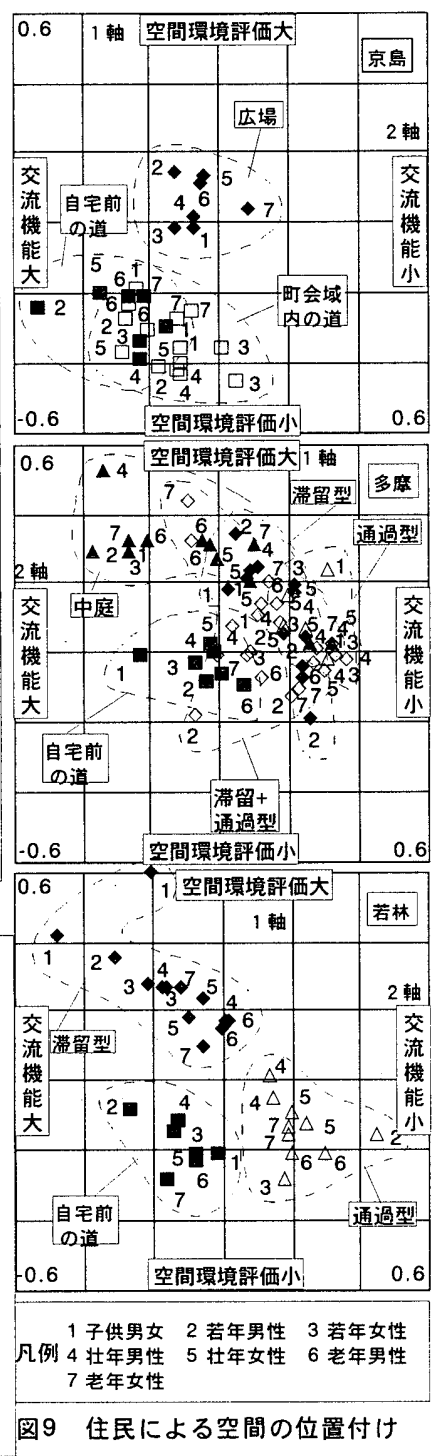
型 
掃徹底·緑化·静寂保持に関する快適性はま多く望まれ、評価が一定水 準に達した空間に対しては快適性維持が保全要件として得られた。

若林地区に関しては、滞留型」通過型」に対する要望内容の比較 を行う。まず現状のままでよいははいずれも少なく、多くの住民に より広場の改善要求が奇せられている。付帯設備側面をみると、通 過型りにおいて(座るところをつくる!揭示板を備える!が比較的多 く、通過型」には歩行者通行を支援する機能の他、地域情報摂取、 鄎いの場としての機能付加が望まれる傾向にある。広場新設の要件 として、|寄り道行為|の誘引が機能に要されると得られた。安全性 については、体の通行を制限するが通過型」に多くみられる。通 過型にについては、歩行者の通行を支援する機能を盛り达む必要があ るものの、同時に安全性改善も望まれており、歩行者の安全を確保 するための機能を強化させること、もしくは車両通過を許容すると すれば、別に歩行者の安全性が確保された[滞留型! 広場を開設する ことが再整備の方向性として得られた。また多摩と同様、「花や木を 増やす」清掃を徹底する!静かな場所にするは は、空間評価の低い 通過型」に多い他、評価が高い「滞留型りにも同様の住民要望が多く 奇せられている。既存の身近な広場を共用空間として機能させるた めには、道路を補完し得る一定水準の安全性·快適性に関する空間性 能向上、及び住民による管理運営を含めた空間快適性維持のあり方 が今後重要な保全要件となる。

\section{5. まとめ}

本報では、都市の既成住宅地を対象とし、住民の領域認知、並び にそこにおける住民の交流の場である共用空間の利用実態、及び評 価と今後の整備の方向性・あり方を求めた。結果を以下にまとめる。 1）住民が認知している領域規模は隣組圈域や町会域程度の居住単位 と対応している。居住単位の地縁的性質肪強い場合、主婦層・高 齢者等の在宅時間が長い階層は、共用空間を身近な認知領域内に 形成している傾向にある。すなわちけナワバリと認知するオープ ンスペースを確保することにより、近隣住民がそれを共用空間と して機能させ得ることが求められた。

2）住宅地の特性に係わらず各地区において、住民の多数が利用する 主要な共用空間と、少数が利用する性格が特化した共用空間が存 在し、共用空間相互に居住者の利用度合や内容に階層性を有する。 共用空間の機能には、日常行為支援や余㗇活動支援、家族間·近隣 住民間における交流支援が挙げられる。身近な道路空間は日常的 な交流行為を支援するものの余暇交流に関する機能は少ない。住 民の身近な認知領域内に機能が異なる共用空間が包含される場合、 空間相互で役割分担がなされるようになる。身近な共用空間にお いても利用者と利用空間の使い分けが生じている。

3）身近な小広場や路地等は、主に在宅時間の長い層が「ナワバリ」 内に捉え、評価の高い空間として位置づけている。特に、路地等 の道路空間が主要な場とされている既成市街地において、広場が、 滞留機能整備に限界のある道路を補完するためには、架間性能の 向上、地区内における配置に偏りのない量的確保が再整備課題で ある。また、配置や機能に偏りなく共用空間が整備され、評価が 一定の水準に達した計画的住宅地では、空間快適性の維持が整備 要件として重要となる。今後、屋外共用空間の保全・再整備計画 にあたり、滞留・通過等の使い分けの状況や、地区ごとの再整備
課題を基盤要件として位置づけることが、近隣住民による管理・・ 運営意識の䤑成に結びつき、共用空間保全へと還元され得る。

今後の研究課題として、住宅地における共用空間を行政サイドが 今後どの様に確保し、それを住民に管理委託するようなシステム構 築の研究が必要と考える。

最後に、アンケート・ヒアリング調查に協力して頂いた各地区の住 民の方々、ならびに区役所職員、町会役員、団地管理組合員の方々 にこの場を借りて心よりお礼申し上げます。

\section{注釈}

1）伊豆大島噴火炎害については筆者らが、参考文献(1)で报った。

2) 参考文献(2) 等で报われている。

3）参考文献(3) 等で共用部分の椎能が示されている。

4）参考文献(4)pp.96「・・こういったプライバシ一重視の傾向は、日本では、高度経済成晨 の期間を通じて急速に强まったものと思われる。それ以前、とくに第二次大戦前までは，

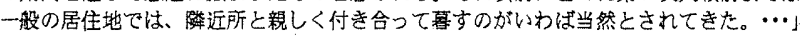
等、既成住宅地にお汁る伝統的な共用空間寝失に関する票及が為されている。

5) 参考文献(5)

6)アンケート調查は対象 3 地区内に住む小学生以上の住民を対象に実施した。調査票は，

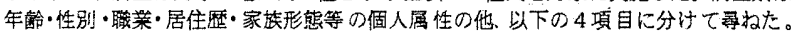
(1)住民による証知領域の区分：けワバリ」と近所1の領域㒛瀻の把握(指示文注注啋

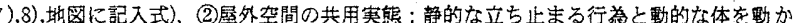
す行為の各内容について、その場所 (小広場や公園に限占す、家の前の道端や空地等あら ゆる場所を抽出するため、(1)之同様地图に記入式)・活動頻度・D緒に行う人の属性等の

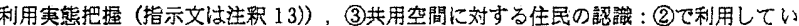

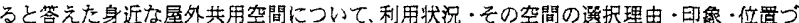
计等の共用認識の把握，(4)身近な屋外㞬間に対する住民の意向：地区ごとに数力所ずう 設定した小広場や路地など身近な屋外架間(2)(3)と同じ場所であることも多いに対して、 利用の有無にかかわらす、近くに住吉住民としての客観的な趾価や整備要望、管理・運営・ 軍用に開する意向等の把握

7）けワバリにとは広辞苑による定義動物の個体や集团が競争者に進入させぬよう占有す る一定の領域に盗じる形で、本研究では!見慣れない人がいると気になる領域(子供層： 戓らない人がいると变だなと思うはんいりとして地図に記入してもらう方法をとった。

8）近所については、調査票において旧頃よく通る道を含む籍囲で、家の近くと感じてい るところ(子供層：あなたの家のまわりでいつもよく通る道など『いえの近く』と思って いるはんいとして住民に帚㸚た。

9）地元住民ヒアリングに基づき、生活道路として商店街の曼側に位置し、混雑して通過の 側面に支障を来す商店街の报け道として住民に幅広く利用されている道を選定した

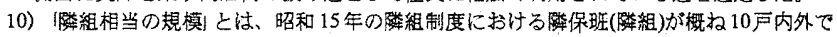

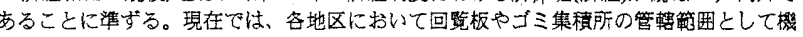
能を果たしている(参考文神(6))

11）子供層に開しては、少数であり男女均等に回答が得られていはいため1階層とした。

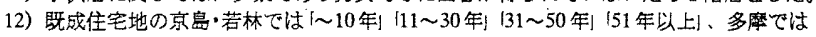
| 5 年1 $16 \sim 10$ 年1 11 年〜 亿居当初時〜」区分を設定した。

13）本研究で核屋外での日常行為を大きく 2 分類し、アンケートで静的に立ち止まる行 為』を行う空間を立ち話やひと休夕，子供を避ばせておくなど立ち止まったり座ったり している場所、『動的に体を動加す行為』の空間を遊びや運動、子供の遊びの相手、清㛿、 花や樹木の手入れをするなど、その場で体を動かしている場所りとして別々に專极た。

14）クラスター分析にはユークリッド平方距離によるウォード法を採用した。

\section{参考文献}

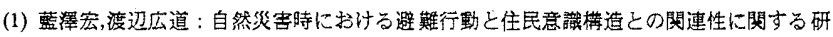
究一昭和 61 年伊豆大島塤火炎客を事例として一, 日本建学会計画系論文報告菓， No.431,pp. $47 \sim 58,1992.1$

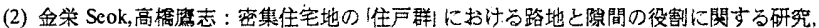

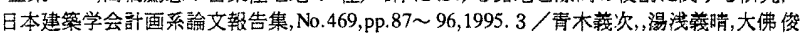
泰:あふれ出しの社会心理学的効果 路地空間へのあ心れ出し調查加ら如計画概念の仮 説と梌証その2，日本建筑学会計画系論文報告重,No.457,pp.125 132,1994.3

(3) 小林秀樹,跲木成文:集合住宅における共有領域の形成に閶する研究その 2 建築形態の影

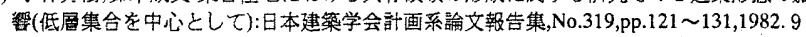

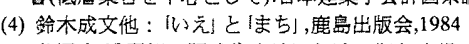

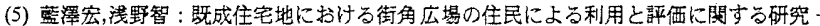
世田谷区太子堂地区の事ヶットパークを事例として一、日本建築学会計画系論文集， No.490,pp.63〜 72,1996.12

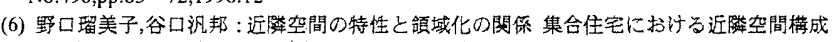

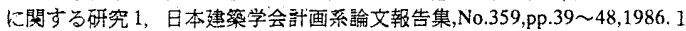

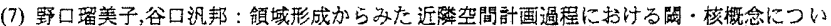

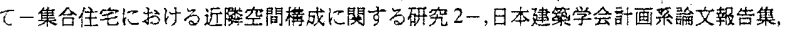
No.368,pp.91 101,1986.10

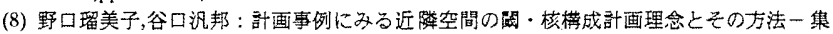

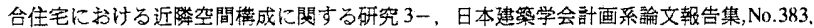
pp. $24 \sim 34,1988.1$

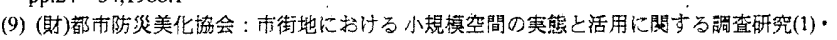
(2), $1990 \cdot 91$

(10) J.Gchl,北原理雄訳：屋外空間の生活とデザイン,鹿岛出版会,1990

(11) 高楅恒，福田成二：公園の利用圈域と地域的性格について 空間の地域的性格に関す る研究 -2 , 日本建築学会計画係論文報告集,No.454,pp.133 143,1993.12

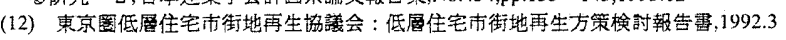

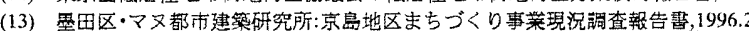

